DOI:

Cite this as:

Ediyanto, Mulyadi, Agus, Supriatna, Agus, Kawai, Norimune. The Education And Training Program Guideline For Special Guidance Teacher Competence Development In Indonesian Inclusive School Indonesian Journal of Disability Studies (IJDS).2018: Vol. 5(2): PP 251-267.

\title{
THE EDUCATION AND TRAINING PROGRAM GUIDELINE FOR SPECIAL GUIDANCE TEACHER COMPETENCE DEVELOPMENT IN INDONESIAN INCLUSIVE SCHOOL
}

\author{
${ }^{1 *}$ Ediyanto, ${ }^{2}$ Agus Mulyadi, ${ }^{2}$ Agus Supriatna, ${ }^{3}$ Norimune Kawai \\ ${ }^{1}$ Student of Graduate School for International Development and Cooperation (1-5-1 Kagamiyama, Higashi-Hiroshima \\ City, Hiroshima, 739-8529, Japan) \\ ${ }^{2}$ WidyaIswara of Centre for Development and Empowerment of Teachers and Education Personnel of Kindergartens and \\ Special Education (Jalan Dr. Cipto No. 9, Bandung, Jawa Barat, 40131, Indonesia) \\ ${ }^{3}$ Professor of Department of Special Needs Education, Graduate School of Education, Hiroshima University, Japan (1-1- \\ 1 Kagamiyama, Higashi-Hiroshima City, Hiroshima, 739-8524, Japan)
}

\begin{abstract}
The provision of inclusive schools in Indonesia requires the fulfillment of several aspects of inclusive education. Fulfillment of these needs include curriculum, facilities and infrastructure, teachers, and learning in accordance with the principles of inclusive education. Teachers in inclusive classes must have the competence to teach students with special needs. In addition, inclusive classes also require special special guidance teachers as instructional design or as team teaching. However, this training program for special guidance teachers has not been developed in a general, comprehensive and integrated manner. So that in this article an education and training program was developed for the teacher competence development guidelines in Indonesian inclusive school. If every school requires at least one special guidance teacher, then at the elementary formal education level, junior high, high school and equivalent schools, the total number of special guidance teachers is 259,244 teachers. While for the kindergarten level the number of teachers is 85 . 499 teachers. Competency Standards for Special Guidance Teachers refer to Minister of National Education Regulation No. 16 of 2007 - Academic Qualification Standards and Competencies of Teachers and Minister of National Education Number 32 of 2008 - Academic Qualification Standards and Competencies of Special Education Teachers. In general, there are four competencies that must be mastered by Special Guidance Teachers, namely Personality, Social, Pedagogic, and Professional Standards. The education and training list is divided into three main parts, namely general education and training subjects, basic training subjects and supporting training subjects. This program has not been validated and field tested. In the next step research it is necessary to validate by experts and field testing to determine the level of validity and effectiveness of the program.
\end{abstract}

Keywords: inclusive education, education and training program, teachers competence

\section{Introduction}

Education is the fundamental right for every child. The world nowadays is taking serious care to deliver school-aged children to complete their primary education. The action was the goal of the "Millennium Development Goals" (MDGs) and "Education for All" (EFA) (Slavin, 2996; WHO, 2008; Rieser, 2012). The Indonesian government also made a political

* Corresponding author: Ediyanto

ediace09@yahoo.co.id

Published online at http://IJDS.ub.ac.id/

Copyright @ 2018 PSLD UB Publishing. All Rights Reserved commitment to "World Education Forum" (2000) to achieve Basic Education for All. As an implementation to actively participate in world activities, the Government of the Republic of Indonesia has enacted a Law on National Education System (Law No.20 / 2003) based on the 1945 Constitution of the Republic of Indonesia. Republic of Indonesia Article 31 paragraph (1) states that every citizen has the right for education and paragraph (2) every 
citizen must take basic education and the government is obliged to finance it.

Furthermore, as stated in the 1945 Constitution of the Republic of Indonesia and the Law on the National Education System, this shows that children with special needs have equal opportunities to get a decent education without exception. One of the efforts to facilitate children with special needs is an special-need school. However, according to data from the Ministry of Education and Culture and BPS, more than 1.6 million children with special needs at school age do not have the opportunity to attend school. More than 32 thousand schools, it can only accommodate less than 300 thousand students (Maulipaksi, 2017; kemdikbud.go.id, bps.go.id). Therefore, more than 1.3 million people with special needs do not have the opportunity to go to school. To give equal rights to get a decent education, Indonesia has developed an inclusive education system.

Inclusive education in Indonesia begins when world issues are committed to the Education for All (EFA) movement. In addition, it refers to the "Salamanca Statement and UNESCO Framework for Action" (1994) which stated that the rights of every child must be educated and recognized about differences in interests, abilities and learning needs. Yet, in its implementation, even after the 2004 Bandung Declaration and the Republic of Indonesia's National Education Minister's Regulation Number 70 of 2009 which confirms the commitment of all parties involved in Indonesia to Inclusive education, up to now the number of inclusive schools in Indonesia is less than 1000 schools from various levels and less than 16 thousands of students with special needs are accommodated (Maulipaksi, 2017; kemdikbud.go.id, bps.go.id).

The domino effect that arises from the problem of the availability of inclusive education schools is to accommodate children with special needs is the fulfillment of all aspects of the inclusive education system such as curriculum, facilities and infrastructure, teachers, and learning in accordance with the principles of inclusive education. Learning for children with special needs has unique characteristics as a result of the physical, psychological, mental, and social conditions of children with special needs. Therefore, being a teacher of children with special needs requires adequate competence. The law of teachers and lecturers, emphasizes that there are four competencies that must be possessed by the teacher that is: pedagogic competence, professional competence, personal competence, and social competence.

The profile of teacher competencies in the inclusive education system, in addition to having general competencies, must also have specific competencies in the learning of children with special needs. Understanding the figure of children with special needs, reviewing curriculum and assessments of children with special needs, learning and evaluation strategies, and reporting of learning outcomes, is a specific competence that must be owned by teachers of children with special needs. Efforts to improve the competence of teachers of children with special needs, can be carried out starting from preservice learning activities, to inservice learning activities. Inservice learning activities, one of which is carried out through activities to improve teacher competencies in inclusive education. Through this training program, the development of teacher competencies can be improved according to the needs in the field.

\section{Understanding of Inclusive Education}

Inclusive education is a system of providing education for children who have certain limitations and other children who are put together without considering the limitations of their respective limitations (Garnida, 2015). According to the Directorate of Special School Development (in Garnida, 2015), inclusive education is a system of education services that provides opportunities for all children to learn together in public schools by taking into account the diversity and individual needs, so that the child's potential can develop optimally. The spirit of inclusive education is to give the widest possible access to all children, including children with special needs, to obtain quality education and provide educational services in accordance with their needs (Granida, 2015). Inclusive education is education that includes all children together in a climate and learning process with appropriate educational services and in accordance with the individual needs of students without discriminating children from ethnic backgrounds, social conditions, 
economic, political, family abilities, language, gograph (remoteness) place of residence, gender, religion, and differences in physical or mental conditions (Ni'matuzahroh \& Nurhamida, 2016).

Inclusive education is an ideal place for all children (Garnida, 2015) regardless of needs especially. The characteristics of inclusive education have 4 meanings that is: 1) Inclusive education is a process that goes on in its efforts to find ways to respond to the diversity of individual children, 2) Inclusive education means obtaining ways to overcome obstacles in learning, 3) Inclusive education means that children have the opportunity to attend school, participate and get meaningful learning outcomes in their lives, and 4)Inclusive education is intended for children who are classified as marginal, exclusive and need special education services in learning.

The main purpose of inclusive education is to educate children with special needs in regular classroom together with normal children with support that is appropriate to their needs in the school that is closest to their place of residence and without discrimination (Stubbs, 2008). In addition, inclusive education will minimize the limitations of the conditions of growth and development of children and to maximize the opportunities for children with special needs to be involved in the same social environment as children in general. Inclusive education also aims to prevent the occurrence of more severe conditions and developmental irregularities that make children more helpless and prevent increasing child powerlessness in other aspects because of their limitations (Ni'matuzahroh \& Nurhamida, 2016).

\section{The Needs for Special Guidance Teachers}

Ediyanto, Atika, Kawai \& Prabowo (2017) in their research stated that in learning in inclusive classes, it is impossible to have only one teacher in a classroom. There are at least one classroom teachers and one special guidance teachers (GPK). Classroom teachers who understand about learning content and classroom guidance teachers who understand how students with special needs learn. Classroom teacher and special guidance teachers (GPK) collaboration will bring the inclusive classes to ideal. However, in accordance with the Minister of National Education Regulation Number 70 of 2009 concerning Inclusive Education in Article 10 which requires district / city governments to provide at least one GPK to a designated education unit. In addition, the provincial government is obliged to assist the tasks to improve competence in the field of special education for educators and education personnel in education units and providers of inclusive education.

Handayani \& Rahadian (2013) suggests that there is still a shortage of teachers in the implementation of inclusive education, especially Special Guidance Teachers (GPK). The existence of GPK is a major problem for inclusive schools located far from special schools (SLB). Based on secondary data from Hellen Keller Foundation - Indonesia, the number of GPKs that have been trained reached 281 people. Ideally, one GPK is for one school with expertise for all disabilities.

The explanation above can be seen that the need for the number of Special Guidance Teachers is as follows.

\subsection{The Need For Special Guidance Teachers According To The Minister Of National Education Regulation Number 70 Of 2009 Concerning Inclusive Education.}

Based on the number of districts / cities, according to data from the Directorate of Regional Arrangement, Special Autonomy, and the Regional Autonomy Advisory Council, Ministry of Home Affairs of the Republic of Indonesia in 2014, the number of autonomous regions in Indonesia is 542 (34 Provinces, 415 districts and 93 cities). The number of Special Guidance Teachers is at least 542 teachers spread in various regions in Indonesia.

\subsection{The Need For Special Guidance Teachers According to the Number of Schools}

According to BPS data for $2015 / 2016$, the number of schools in Indonesia can be seen in table 1 .

Table 1. Number of Needs for Special Guidance Teachers Based on Number of Schools

\begin{tabular}{llr}
\hline No & Grade & \multicolumn{1}{c}{ Total } \\
\hline 1 & Senior High School & 33.191 \\
\hline 2 & Junior High School & 53.957 \\
\hline 3 & Elementary School & 172.096 \\
\hline
\end{tabular}




\begin{tabular}{lrr}
\hline 4 & Kindergarten & 85.499 \\
\hline Total & & 344.743 \\
\hline \multicolumn{3}{c}{ Source: $w w w . b p s . g o . i d$} \\
\end{tabular}

\subsection{The need for special guidance} teachers (GPK) according to the number of classes

This condition is an ideal condition for inclusive education. Each inclusive classes has classroom teachers and special guidance teachers (GPK). This condition can be fulfilled through the stages of fulfillment of the number of special guidance teachers (GPK) by district / city and according to the number of schools fulfilled.

\section{Understanding of Special Guidance Teachers (GPK)}

In Indonesia, there are three laws and regulations governing GPK. These laws and regulations are:

a. Minister of National Education Regulation Number 70 of 2009 concerning Inclusive Education for Students Who Have Abnormalities and Have Special Intelligence and / or Talent Potential.

\section{Article 10}

(1) The regency / city government is obliged to provide at least 1 (one) special guidance teacher to the education unit designated to organize inclusive education.

(2) The education unit of inclusive education providers who are not appointed by the district / city government must provide at least 1 (one) special guidance teacher.

(3) The district / city government is obliged to improve competence in the field of special education for educators and education personnel in the education unit that organizes inclusive education.

(4) The Government and the provincial government assist and provide special supervisors for the education unit for inclusive education providers who need it according to their authority.

(5) The Government and the provincial government help improve competence in the field of special education for educators and education personnel in the education unit that organizes inclusive education.

(6) Competency enhancement as referred to in paragraph (3) and paragraph (5) can be done through:
- Center for Development and Empowerment of Educators and Education Personnel (P4TK);

- Educational Quality Assurance agency (LPMP);

- $\quad$ University (PT);

- Other education and training institutions within the regional government, the Ministry of National Education and / or the Ministry of religion;

- Teacher / Principal Working Groups (KKG, KKS), School Supervisory Working Groups (KKPS), MGMP, MKS, MPS and the like.

b. Government Regulation (PP) No.19 of 2005 concerning National Education Education Standards.

Article 41

(1) Every education unit that carries out inclusive education must have education personnel who have the competence to organize learning for students with special needs.

c. Minister of Empowerment of State Apparatus and Bureaucratic Reform Regulation No. 16 of 2009 concerning Teacher Professionals and Credit Numbers

Chapter VII Details of Assessed Activities and Elements

Article 13

(4) Teachers other than carrying out the activities referred to in paragraph (1), paragraph (2), or paragraph (3) can carry out additional tasks and / or other tasks relevant to the function of the school / madrasah as:

- Special guidance teachers for the education unit that organizes inclusive education

Based on the three regulations above the Special Advisor teachers (GPK) have not been specifically defined. According to the page that teaches about Special Guidance Teachers (pinplb.com/gpk) are teachers who serve as learning consultants for children with special needs in inclusive education institutions. As for the duties of the Special Counselor Teacher as follows. 1) Having responsibility as a consultant for the implementation of inclusive education in schools, 2) Collect data about students with special needs in schools as a basis for preparing individual learning programs and individual learning plans, 3) Collaborate with 
class teachers, counceling teachers and other relevant parties in the preparation of individual learning programs and individual learning plans, 4) Modifying learning that is appropriate to the needs of the class which includes the implementation plan of learning, facilities and infrastructure and assessment, and 5) Conduct regular monitoring of the achievement of the implementation of learning in inclusive schools.

Contrary to the above understanding that special guidance teachers are not involved in classroom learning. According to Zeiger (2018), the role of special guidance teachers is involved in classroom learning. Special guidance teachers have assignments namely, 1) together with the class teacher to design a learning plan to suit the needs of students, 2) Evaluate learning outcomes and develop review material for individual learning programs that are suitable for the needs of students with special needs before or after learning, 3) Not focusing on students with special needs alone, special guidance teachers are also responsible for helping general education teachers manage the class, and 4) Helps regulate classroom rules and routines, working with classroom teachers to create a comfortable climate in the classroom.

Based on the explanation above, there are two understandings of special guidance teachers, namely special guidance teacher as instructional design and teacher as team teaching (can be seen on picture 1). Special guidance teacher as instructional design means the teacher is a little involved in classroom learning. The involvement of teachers in this understanding is to identify the special needs of students with special needs in classroom. Whereas for the special mentoring teacher as team teaching means the teacher is directly involved in learning in classes together with the classroom teacher.

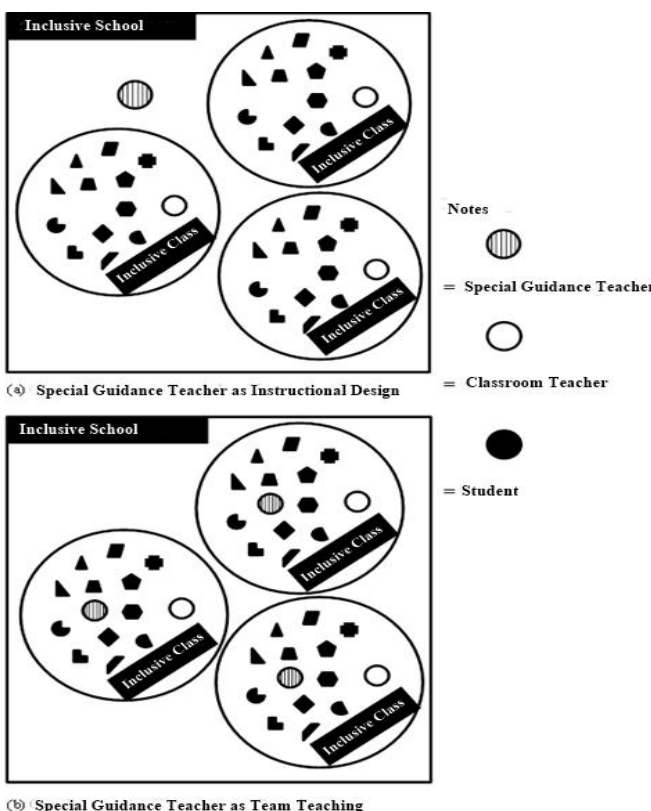

Figure 1. The understanding of Special Guidance Teacher as Instructional Design and Team Teaching

\section{Education and Training Program for Competence Development of Special Guidance Teachers}

\subsection{Program Objectives and Participants}

This Special Guidance Teacher Development Competency Development Education and Training Program is a classroom teacher in regular schools (inclusive schools), special school teachers, or prospective special guidance teachers who are recruited directly (appointments from undergraduate or general) throughout Indonesia (can be seen on picture 2). The number of program participants to meet the number of Special Guidance Teachers in each formal school is 1 school 1 special guidance teacher. Based on the number of formal elementary, junior high, high school and equivalent schools, the total number of special guidance teachers is 259,244 teachers. While for the kindergarten level the number of teachers is 85. 499 teachers. While the implementation is a step that is adjusted to the approach method and method of the Special Guidance Teacher Competency Development Training and Education Program. 


\subsection{Objective}

Educational Goals and Special Competency Teacher Development Competency Training as follows

a. Develop general knowledge about the principles of learning in inclusive education.

b. Improve technical skills in designing learning in inclusive classroom settings.

c. Develop practical experience and deepening specialization types of children with special needs in learning settings in inclusive schools.

\subsection{Benefits}

The expected benefits after the implementation of this Special Guidance Teacher Competency Development Education and Training Program are:

a. Have the same understanding about the principles of learning in inclusive education.

b. Increased technical skills of special guidance teachers in designing learning in inclusive classroom settings

c. Increased practical experience and deepening specialization types of children with special needs in learning settings in inclusive schools.

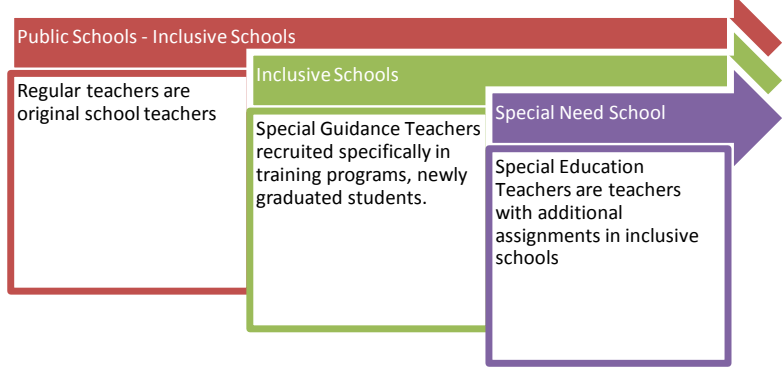

Figure 2. Program participants can come from public school teachers, newly graduated students, and extraordinary school teachers.

\subsection{Special Guidance \\ Competency Standards (SKG)}

Teacher

Competency Standards (SKG) for Special

Guidance Teachers refer to Minister of National

Education Regulation No. 16 of 2007 -

Academic Qualification Standards and Competencies of Teachers and Minister of National Education Number 32 of 2008 Academic Qualification Standards and Competencies of Special Education Teachers. In general, there are four competencies that must be mastered by Special Guidance
Teachers, namely Personality, Social, Pedagogic, and Professional Standards (can be seen on picture 3 ).

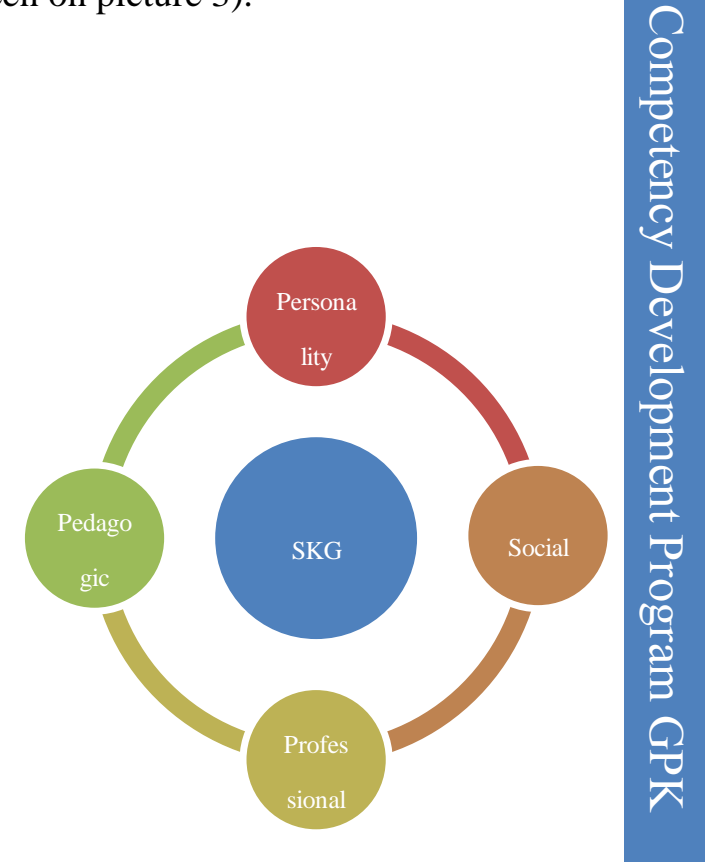

Figure 3. Competency Standart of Special Guidance Teachers in Indonesia

\subsection{Approaches and Methods}

Strategies in the Education and Special Teacher Competency Development Training Program are the principles of effective, efficient and sustainable. Effective principles in this program can be described as follows. 1) Using an adult learning approach with active and fun learning method, 2) Provide various applications and learning methods for children with special needs, 3) Maximizing the use of multimedia in the implementation of education and training, and 4) Using portfolio assessment models in evaluating the results of training.

To support the use of the above strategies, various training and training methods were used in this training through material input, discussion and question and answer, brainstorming, games, assignments, group work, peer teaching, classroom teaching practices, group dynamics, and other methods relevant. The efficient principle in this program are having a structured report and reported as an evaluation material for the subsequent program implementation and having an integrated database that is thoroughly and openly accessed with the aim of equitable training programs. The sustainable principle in this program are have clear monitoring of special mentoring teachers who have participated in the program, 
evaluating special mentoring teachers who have participated in the program, and become a source of knowledge for other teachers who have not participated in the program.

\subsection{Components and Activity Flow}

The special Guidance Teacher Development and Competency Development Training series includes three phases of activities, namely preparation, implementation and evaluation and follow-up plans (can be seen on picture 4).

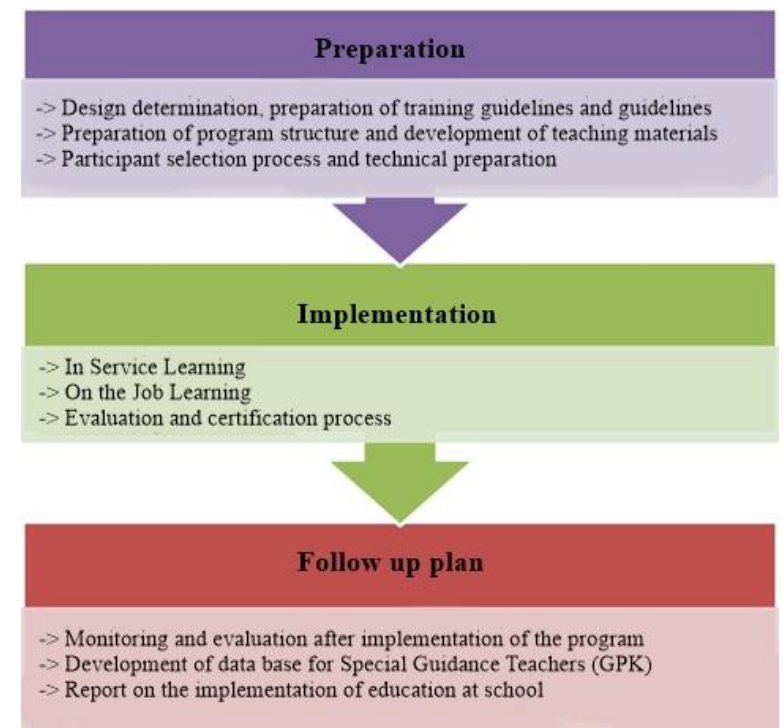

Figure 4. Components and Activity Flow of Program

\subsection{Structure and Description of Program Implementation}

The implementation phase of the Teacher Competency Development Education and Training Special Advisor is planning three stages, namely in service learning, on the job learning and evaluation and certification. The education and training list is divided into three main parts, namely general education and training subjects, basic training subjects and supporting training subjects. The general education and training subjects consist of 4 topics with a total of 10 hours of study. The main training subjects consist of 39 topics with a total of 424 study hours. In this subject there is one subject "On the Job Learning" as much as 50 hours of lessons held at school. Whereas for supporting training subjects consists of 4 topics with a total of 16 hours of study. Full description of the program structure in Appendix 1 and an explanation of the structure of program implementation in Appendix 2.

\subsection{Resource persons and facilitators}

The resource persons and facilitators for this Special Counseling Teacher Development and Competency Development Program are from PPPPTK Kindergarten and PLB trainers, competent College Academics and competent qualified Field Practitioners.

\subsection{Funding}

The cost of implementing this Special Guidance Teacher Development and Competency Education Program can come from the budgets of all parties related to the development of inclusive education such as the Central Government, Regional Governments, Universities, Community Institutions, CSR, Foreign Aid Funds, or Mandiri. Funding schemes can be through independent funds or partnerships.

\section{Conclusion}

This Guidance for Special Guidance Teacher Development Education and Training Program (GPK) is developed based on theoretical basis, legislation and a thorough understanding of inclusive education. Through this guideline, it is hoped that it can provide a clear and comprehensive overview of the Education Program and Training for the Development of Special Guidance for Teacher Guidance and can contribute to the improvement of the competence of special supervisor teachers. Hopefully this program can be implemented for the success of Indonesian Education in general and for Indonesian Inclusive Education in particular.

\section{Future Directions}

The program entitled "The Education and Training Guidelines for Special Guidance Teacher Development in Indonesian Inclusive Schools" has not been validated and field tested. In the next step research it is necessary to validate by experts and field testing to determine the level of validity and effectiveness of the program. Validation and field testing processes aim to evaluate and improve the program. In addition, based on reviews conducted by Teacher Training at the PPPPTK TK and PLB (called WidyaIswara), it is necessary to undertake tiered training in a shorter period of time. Suppose it is divided into training, basic, intermediate, advanced and

Ediyanto, Mulyadi, Agus, Supriatna, Agus, Kawai, Norimune. The Education And Training Program Guideline For Special Guidance Teacher Competence Development In Indonesian Inclusive School Indonesian Journal of Disability Studies (IJDS).2018: Vol. 5(2): PP 251-267. 
high stages. This can be an indicator of the level of the ability of special guidance teachers and improve the certification process. In addition, in the next stage it is necessary to develop teaching materials and assessment tools in accordance with the guidelines of this training program.

\section{References}

Bandung Declaration.

(2004).

www.idpeurope.org.

Ediyanto, E., Atika, I. N., Kawai, N., \& Prabowo, E. (2017). Inclusive Education In Indonesia From The Perspective Of Widyaiswara In Centre For Development And Empowerment Of Teachers And Education Personnel Of Kindergartens And Special Education. INDONESIAN JOURNAL OF DISABILITY STUDIES (IJDS), 4(2), 104-116. Handayani, T., \& Rahadian, A. S. (2013). Peraturan perundangan dan implementasi pendidikan inklusif. Masyarakat Indonesia, 39(1), 27-48. https://kemdikbud.go.id https://www.bps.go.id

Indonesia, U. U. D. N. R. (1945). Tahun 1945. Kitab Undang-undang Hukum Perdata. Herzien Inlandsch Reglement.

Garnida, Dadang. (2015). Pengantar

Pendidikan Inklusif. Bandung : Refika Aditama.

Government Regulation Number 72 of 1991

concerning Special Education.

Government Regulation of the Republic of Indonesia Number 32 of 2013 concerning National Education Standards.

Government Regulation no. 74 of 2008 concerning Teacher.

Government Regulation (PP) No.19 of 2005 concerning National Education Education Standards.

Law of the Republic of Indonesia Number 20 of 2003 concerning the National Education System.

Maulipaksi, D. (2017). Sekolah inklusi dan pembangunan SLB dukung pendidikan inklusi. Retrieved on July, 19, 2017.
Minister of National Education Regulation No. 41 of 2012 concerning Organization and Work Procedure of Centers for the Development and Empowerment of Educators and Education Personnel.

Minister of National Education Regulation No. 16 of 2007 concerning Academic Qualification Standards and Teacher's Competencies.

Minister of National Education Regulation Number 32 of 2008 concerning Academic Qualification Standards and Competencies of Special Education Teachers.

Minister of National Education Regulation Number 70 of 2009 concerning Inclusive Education for Students Who Have Abnormalities and Have Special Intelligence and / or Talent Potential.

Minister of Empowerment of State Apparatus and Bureaucratic Reform Regulation No. 16 of 2009 concerning Teacher Professionals and Credit Numbers.

Ni'matuzahroh, \& Nurhamida, Y. (2016).

Individu Berkebutuhan Khusus dam Pendidikan Inklusif. Penerbitan Universitas

Muhammadiyah Malang : Malang.

Rieser, R. (2012). Implementing inclusive education: a Commonwealth guide to implementing Article 24 of the UN Convention on the Rights of Persons with Disabilities. Commonwealth Secretariat.

Slavin, R. E. (1996). Education for all. CRC

Press.

Stubbs, S. (2008). Inclusive Education. Where

there are few resources. Oslo, The Atlas

Alliance Publ.

Unesco. (1994). The Salamanca Statement and Framework for action on special needs education: adopted by the World Conference on Special Needs Education; Access and Quality. Salamanca, Spain, 7-10 June 1994. Unesco.

World Health Organization. (2008). Millennium development goals. 


\section{Appendix 1. Implementation Program Structure}

\begin{tabular}{|c|c|c|c|}
\hline Program & Subject & Code & $\begin{array}{l}\text { Total } \\
\text { Hour }\end{array}$ \\
\hline \multirow[t]{4}{*}{$\begin{array}{l}\text { A. } \\
\text { General }\end{array}$} & $\begin{array}{l}\text { 1. Ministry of } \\
\text { Education and Culture } \\
\text { Policy }\end{array}$ & $\overline{\mathrm{A} 1}$ & 2 \\
\hline & $\begin{array}{l}\text { 2. Local Education } \\
\text { Policy }\end{array}$ & A2 & 2 \\
\hline & $\begin{array}{l}\text { 3. Culture and Nation } \\
\text { Character Education }\end{array}$ & A3 & 4 \\
\hline & $\begin{array}{l}\text { 4. Design and } \\
\text { Technique for the } \\
\text { Implementation of } \\
\text { Special Counseling } \\
\text { Teacher Competency } \\
\text { Training }\end{array}$ & A4 & 2 \\
\hline \multirow[t]{15}{*}{ B. Basic } & $\begin{array}{l}\text { 1. Inclusive School } \\
\text { Capital }\end{array}$ & B1 & 8 \\
\hline & $\begin{array}{l}\text { 2. Profile of Special } \\
\text { Guidance Teacher } \\
\text { Competencies }\end{array}$ & B2 & 6 \\
\hline & $\begin{array}{l}\text { 3. Educational } \\
\text { Psychology }\end{array}$ & B3 & 6 \\
\hline & 4. Inclusive Education & B4 & 6 \\
\hline & $\begin{array}{l}\text { 5. Identification and } \\
\text { Assessment of Children } \\
\text { with Special Needs }\end{array}$ & B5 & 10 \\
\hline & $\begin{array}{l}\text { 6. Learning for Blind } \\
\text { Children }\end{array}$ & B6 & 10 \\
\hline & $\begin{array}{l}\text { 7. Writing and Reading } \\
\text { Braille }\end{array}$ & B7 & 10 \\
\hline & $\begin{array}{l}\text { 8. Orientation and } \\
\text { Mobility }\end{array}$ & B8 & 10 \\
\hline & $\begin{array}{l}\text { 9. Learning for Deaf } \\
\text { Children }\end{array}$ & B9 & 10 \\
\hline & $\begin{array}{l}\text { 10. Deafness, Language } \\
\text { Development and } \\
\text { Needs of } \\
\text { Communication } \\
\text { Perceptions of Sound } \\
\text { and Rhythm }\end{array}$ & B10 & 10 \\
\hline & $\begin{array}{l}\text { 11. Principles, } \\
\text { Techniques and } \\
\text { Learning Procedures } \\
\text { for Communication } \\
\text { Perceptions of Sound } \\
\text { and Rhythm }\end{array}$ & B11 & 10 \\
\hline & $\begin{array}{l}\text { 12. Learning for } \\
\text { Mentally Retarded } \\
\text { Children }\end{array}$ & B12 & 10 \\
\hline & $\begin{array}{l}\text { 13. Self-Development } \\
\text { Program }\end{array}$ & B13 & 10 \\
\hline & $\begin{array}{l}\text { 14. Learning for Slow } \\
\text { Learning Children }\end{array}$ & B14 & 10 \\
\hline & $\begin{array}{l}\text { 15. Learning for } \\
\text { Children with }\end{array}$ & B15 & 10 \\
\hline
\end{tabular}

\begin{tabular}{|c|c|c|c|}
\hline Program & Subject & Code & $\begin{array}{l}\text { Total } \\
\text { Hour }\end{array}$ \\
\hline & Impairment & & \\
\hline & $\begin{array}{l}\text { 16. Motion } \\
\text { Development Program }\end{array}$ & B16 & 10 \\
\hline & $\begin{array}{l}\text { 17. Sustainable } \\
\text { Professional } \\
\text { Development }\end{array}$ & B17 & 10 \\
\hline & $\begin{array}{l}\text { 18. Spiritual } \\
\text { Development in } \\
\text { Inclusive Schools }\end{array}$ & B18 & 10 \\
\hline & $\begin{array}{l}\text { 19. Learning for } \\
\text { Autistic Children }\end{array}$ & B19 & 10 \\
\hline & $\begin{array}{l}\text { 20. Management of the } \\
\text { Behavior of Autistic } \\
\text { Children }\end{array}$ & B20 & 10 \\
\hline & $\begin{array}{l}\text { 21. Picture Exchange } \\
\text { Communication System } \\
\text { (PECS) }\end{array}$ & B21 & 10 \\
\hline & $\begin{array}{l}\text { 22. Learning for } \\
\text { Children with Learning } \\
\text { Difficulties }\end{array}$ & B22 & 10 \\
\hline & $\begin{array}{l}\text { 23. ICT-based Student } \\
\text { with Special Needs } \\
\text { learning }\end{array}$ & B23 & 10 \\
\hline & $\begin{array}{l}\text { 24. Learning Media for } \\
\text { Student with Special } \\
\text { Needs }\end{array}$ & B24 & 10 \\
\hline & 25. Adaptive Guidance & B25 & 10 \\
\hline & $\begin{array}{l}\text { 26. Approaches, } \\
\text { Strategies and } \\
\text { Learning Methods } \\
\text { for Student with } \\
\text { Special Needs }\end{array}$ & B26 & 20 \\
\hline & $\begin{array}{l}\text { 27. Student with } \\
\text { Special Needs Class } \\
\text { Management }\end{array}$ & B27 & 8 \\
\hline & $\begin{array}{l}\text { 28. Learning for Gifted } \\
\text { Children }\end{array}$ & B28 & 10 \\
\hline & $\begin{array}{l}\text { 29. Vocational For } \\
\text { Student with Special } \\
\text { Needs }\end{array}$ & B29 & 10 \\
\hline & $\begin{array}{l}\text { 30. Curriculum } \\
\text { Development for } \\
\text { Student with Special } \\
\text { Needs }\end{array}$ & B30 & 10 \\
\hline & $\begin{array}{l}\text { 31. Syllabus and lesson } \\
\text { plan for Student with } \\
\text { Special Needs }\end{array}$ & B31 & 10 \\
\hline & $\begin{array}{l}\text { 32. Learning } \\
\text { Evaluation for Student } \\
\text { with Special Needs }\end{array}$ & B32 & 10 \\
\hline & $\begin{array}{l}\text { 33. Classroom Action } \\
\text { Research }\end{array}$ & B33 & 10 \\
\hline & $\begin{array}{l}\text { 34. Single Subject } \\
\text { Research }\end{array}$ & B34 & 10 \\
\hline & $\begin{array}{l}\text { 35. Guidance and } \\
\text { Counseling for Student }\end{array}$ & B35 & 8 \\
\hline
\end{tabular}


IJDS 2018; Vol. 5 No. 2, November 2018, pp. 251-267

ISSN: $2355-2158$, e-ISSN: 2654-4148

DOI:

\begin{tabular}{|l|l|c|c|}
\hline \hline \multirow{1}{*}{ Program } & \multicolumn{1}{|c|}{ Subject } & Code & $\begin{array}{c}\text { Total } \\
\text { Hour }\end{array}$ \\
\hline \hline \multirow{5}{*}{} & with Special Needs & & \\
\cline { 2 - 4 } & $\begin{array}{l}\text { 36. Nutrition and } \\
\text { Health in Student with } \\
\text { Special Needs }\end{array}$ & B36 & 6 \\
\cline { 2 - 4 } & $\begin{array}{l}\text { 37. Cooperation } \\
\text { between Parents and } \\
\text { Schools }\end{array}$ & B37 & 6 \\
\cline { 2 - 4 } & $\begin{array}{l}\text { 38. Project-Based } \\
\text { Learning Model }\end{array}$ & B38 & 20 \\
\cline { 2 - 4 } & $\begin{array}{l}\text { 39. On the Job } \\
\text { Learning }\end{array}$ & B39 & 50 \\
\hline C. & 1. Group Dynamics & C1 & 4 \\
\cline { 2 - 4 } Support & $\begin{array}{l}\text { 1. Laboratory } \\
\text { Utilization Student with } \\
\text { Special Needs }\end{array}$ & C2 & 4 \\
\cline { 2 - 4 } & 3. Physical Fitness & C3 & 6 \\
\cline { 2 - 4 } & 4. Action Plan & C4 & 2 \\
\hline TOTAL & & & $\mathbf{4 5 0}$ \\
\hline
\end{tabular}

Cite this as:

Ediyanto, Mulyadi, Agus, Supriatna, Agus, Kawai, Norimune. The Education And Training Program Guideline For Special Guidance Teacher Competence Development In Indonesian Inclusive School Indonesian Journal of Disability Studies (IJDS).2018: Vol. 5(2): PP 251-267. 
Appendix 2. Implementation Program Description

\begin{tabular}{|c|c|c|c|c|c|c|c|}
\hline \multicolumn{4}{|c|}{ Descripu } & & & & \multirow{4}{*}{$\begin{array}{l}\text { inclusive } \\
\text { education at the } \\
\text { policy, } \\
\text { conceptual, and } \\
\text { empirical } \\
\text { levels as a } \\
\text { frame of mind } \\
\text { for the } \\
\text { development of } \\
\text { special mentor } \\
\text { teachers. }\end{array}$} \\
\hline No & Subject & JPL & $\begin{array}{c}\text { Subject's } \\
\text { Description }\end{array}$ & & & & \\
\hline \multicolumn{4}{|c|}{ General Program } & & & & \\
\hline \multirow[t]{2}{*}{1.} & \multirow[t]{2}{*}{$\begin{array}{l}\text { Government } \\
\text { Policy in } \\
\text { Education }\end{array}$} & \multirow[t]{2}{*}{2} & \multirow{2}{*}{$\begin{array}{l}\text { Inform policy } \\
\text { studies and } \\
\text { actual issues } \\
\text { about the } \\
\text { policies of the } \\
\text { Ministry of } \\
\text { Education and } \\
\text { Culture in } \\
\text { developing } \\
\text { teacher } \\
\text { professionalism } \\
\text { nationally. }\end{array}$} & & & & \\
\hline & & & & \multirow[t]{2}{*}{2.} & \multirow{2}{*}{$\begin{array}{l}\text { Profile of } \\
\text { Special } \\
\text { Guidance } \\
\text { Teacher } \\
\text { Competencies }\end{array}$} & \multirow[t]{2}{*}{6} & \multirow{2}{*}{$\begin{array}{l}\text { Explain the } \\
\text { four } \\
\text { competencies } \\
\text { of special } \\
\text { guidance } \\
\text { teachers and } \\
\text { their } \\
\text { elaboration in } \\
\text { the main tasks } \\
\text { as educators for } \\
\text { children with } \\
\text { special needs. }\end{array}$} \\
\hline \multirow[t]{2}{*}{2.} & \multirow[t]{2}{*}{$\begin{array}{l}\text { Local } \\
\text { Government } \\
\text { Policy in Special } \\
\text { Coaching } \\
\text { Teacher } \\
\text { Guidance }\end{array}$} & \multirow[t]{2}{*}{2} & \multirow[t]{2}{*}{$\begin{array}{l}\text { Inform the } \\
\text { local Education } \\
\text { Office program } \\
\text { in coaching and } \\
\text { improving the } \\
\text { competence of } \\
\text { special } \\
\text { guidance } \\
\text { teachers. }\end{array}$} & & & & \\
\hline & & & & \multirow[t]{2}{*}{3.} & \multirow{2}{*}{$\begin{array}{l}\text { Educational } \\
\text { Psychology }\end{array}$} & \multirow[t]{2}{*}{6} & \multirow[b]{2}{*}{$\begin{array}{l}\text { Presenting } \\
\text { rational, } \\
\text { concept, and } \\
\text { benefits of } \\
\text { educational } \\
\text { psychology } \\
\text { studies for the } \\
\text { benefit of } \\
\text { student with } \\
\text { special needs } \\
\text { learning }\end{array}$} \\
\hline \multirow[t]{2}{*}{3.} & \multirow[t]{2}{*}{$\begin{array}{l}\text { National Culture } \\
\text { and Character } \\
\text { Education }\end{array}$} & \multirow[t]{2}{*}{4} & \multirow{2}{*}{$\begin{array}{l}\text { Presenting } \\
\text { orientation and } \\
\text { concept of } \\
\text { National } \\
\text { Character and } \\
\text { Culture } \\
\text { Education, as } \\
\text { well as } \\
\text { analyzing } \\
\text { social problems } \\
\text { in Cultural and } \\
\text { Character } \\
\text { Education } \\
\text { settings. }\end{array}$} & & & & \\
\hline & & & & \multirow[t]{4}{*}{4.} & \multirow[t]{4}{*}{$\begin{array}{l}\text { Inclusive } \\
\text { Education }\end{array}$} & \multirow[t]{4}{*}{6} & \multirow{4}{*}{$\begin{array}{l}\text { Presenting } \\
\text { philosophical } \\
\text { reviews, } \\
\text { policies, } \\
\text { conceptual, } \\
\text { management of } \\
\text { the } \\
\text { implementation } \\
\text { of inclusive } \\
\text { education, and } \\
\text { empirical } \\
\text { analysis of the } \\
\text { implementation } \\
\text { of inclusive } \\
\text { education in } \\
\text { Indonesia. }\end{array}$} \\
\hline 4 & $\begin{array}{l}\text { Design and } \\
\text { Technique for } \\
\text { the } \\
\text { Implementation } \\
\text { of Special } \\
\text { Counseling } \\
\text { Teacher } \\
\text { Competency } \\
\text { Training }\end{array}$ & 2 & $\begin{array}{l}\text { Explain the } \\
\text { design and } \\
\text { techniques of } \\
\text { implementing } \\
\text { special training } \\
\text { for teacher } \\
\text { guidance } \\
\text { competencies. }\end{array}$ & & & & \\
\hline \multicolumn{4}{|c|}{ Main Program } & & & & \\
\hline \multirow[t]{2}{*}{1.} & \multirow{2}{*}{$\begin{array}{l}\text { Inclusive School } \\
\text { Capital }\end{array}$} & \multirow[t]{2}{*}{8} & \multirow[b]{2}{*}{$\begin{array}{l}\text { Explain the } \\
\text { Scientific } \\
\text { Structure of } \\
\text { Inclusive } \\
\text { Education and } \\
\text { the actual } \\
\text { issues that } \\
\text { accompany the } \\
\text { development of }\end{array}$} & & & & \\
\hline & & & & 5. & $\begin{array}{l}\text { Identification } \\
\text { and Assessment } \\
\text { of Children with } \\
\text { Special Needs }\end{array}$ & 10 & $\begin{array}{l}\text { Presenting } \\
\text { basic concepts } \\
\text { of the character } \\
\text { of student with } \\
\text { special needs, } \\
\text { concepts of } \\
\text { identification }\end{array}$ \\
\hline
\end{tabular}




\begin{tabular}{|c|c|c|c|}
\hline No & Subject & JPL & $\begin{array}{c}\text { Subject's } \\
\text { Description }\end{array}$ \\
\hline & & & $\begin{array}{l}\text { and } \\
\text { assessment, } \\
\text { and techniques } \\
\text { for carrying out } \\
\text { assessments for } \\
\text { student with } \\
\text { special needs. }\end{array}$ \\
\hline 6. & $\begin{array}{l}\text { Learning for } \\
\text { Blind Children }\end{array}$ & 10 & $\begin{array}{l}\text { Presenting the } \\
\text { concept of } \\
\text { children with } \\
\text { visual } \\
\text { impairment, } \\
\text { orientation and } \\
\text { learning } \\
\text { principles that } \\
\text { are appropriate } \\
\text { to the needs of } \\
\text { developing the } \\
\text { potential of } \\
\text { blind children. }\end{array}$ \\
\hline 7. & $\begin{array}{l}\text { Writing and } \\
\text { Reading Braille }\end{array}$ & 10 & $\begin{array}{l}\text { Presenting } \\
\text { concepts, } \\
\text { principles and } \\
\text { forms of } \\
\text { braille, and } \\
\text { applying steps } \\
\text { to read and } \\
\text { write braille. }\end{array}$ \\
\hline 8. & $\begin{array}{l}\text { Orientation and } \\
\text { Mobility }\end{array}$ & 10 & $\begin{array}{l}\text { Presenting } \\
\text { concepts and } \\
\text { principles and } \\
\text { techniques of } \\
\text { orientation and } \\
\text { mobility } \\
\text { learning. }\end{array}$ \\
\hline 9. & $\begin{array}{l}\text { Learning for } \\
\text { Deaf Children }\end{array}$ & 10 & $\begin{array}{l}\text { Presenting the } \\
\text { concept of deaf } \\
\text { children, } \\
\text { orientation and } \\
\text { learning } \\
\text { principles that } \\
\text { are compatible } \\
\text { with the } \\
\text { potential } \\
\text { development } \\
\text { needs of deaf } \\
\text { children. }\end{array}$ \\
\hline 10. & $\begin{array}{l}\text { Deafness, } \\
\text { Language } \\
\text { Development } \\
\text { and Needs of } \\
\text { Communication } \\
\text { Perceptions of } \\
\text { Sound and } \\
\text { Rhythm }\end{array}$ & 10 & $\begin{array}{l}\text { Presenting } \\
\text { concepts of } \\
\text { hearing } \\
\text { impairment, } \\
\text { analysis of } \\
\text { language } \\
\text { development of } \\
\text { deaf children, } \\
\text { and } \\
\text { background on }\end{array}$ \\
\hline
\end{tabular}

\begin{tabular}{|c|c|c|c|}
\hline No & Subject & JPL & $\begin{array}{c}\text { Subject's } \\
\text { Description }\end{array}$ \\
\hline & & & $\begin{array}{l}\text { the importance } \\
\text { of BKPBI } \\
\text { programs for } \\
\text { deaf children. }\end{array}$ \\
\hline 11. & $\begin{array}{l}\text { Principles, } \\
\text { Techniques and } \\
\text { Learning } \\
\text { Procedures for } \\
\text { Communication } \\
\text { Perceptions of } \\
\text { Sound and } \\
\text { Rhythm }\end{array}$ & 10 & $\begin{array}{l}\text { Presenting } \\
\text { principles, } \\
\text { techniques, and } \\
\text { learning } \\
\text { procedures for } \\
\text { BKPBI. }\end{array}$ \\
\hline 12. & $\begin{array}{l}\text { Learning for } \\
\text { Mentally } \\
\text { Retarded } \\
\text { Children }\end{array}$ & 10 & $\begin{array}{l}\text { Presenting the } \\
\text { concept of } \\
\text { mentally } \\
\text { retarded } \\
\text { children, } \\
\text { orientation and } \\
\text { learning } \\
\text { principles that } \\
\text { are in } \\
\text { accordance } \\
\text { with the needs } \\
\text { of developing } \\
\text { the potential of } \\
\text { mentally } \\
\text { retarded } \\
\text { children. }\end{array}$ \\
\hline 13. & $\begin{array}{l}\text { Self- } \\
\text { Development } \\
\text { Program }\end{array}$ & 10 & $\begin{array}{l}\text { Presenting } \\
\text { concepts, } \\
\text { principles, } \\
\text { forms, and } \\
\text { techniques of } \\
\text { self- } \\
\text { development } \\
\text { program } \\
\text { learning. }\end{array}$ \\
\hline 14. & $\begin{array}{l}\text { Learning for } \\
\text { Slow Learning } \\
\text { Children }\end{array}$ & 10 & $\begin{array}{l}\text { Presenting the } \\
\text { concept of slow } \\
\text { learning } \\
\text { children, } \\
\text { orientation and } \\
\text { learning } \\
\text { principles that } \\
\text { are in } \\
\text { accordance } \\
\text { with the needs } \\
\text { of the } \\
\text { development of } \\
\text { the potential of } \\
\text { slow learning } \\
\text { children. }\end{array}$ \\
\hline 15. & $\begin{array}{l}\text { Learning for } \\
\text { Children with } \\
\text { Impairment }\end{array}$ & 10 & $\begin{array}{l}\text { Presenting the } \\
\text { concept of } \\
\text { child } \\
\text { impairment, } \\
\text { orientation and }\end{array}$ \\
\hline
\end{tabular}




\begin{tabular}{|c|c|c|c|}
\hline No & Subject & JPL & $\begin{array}{c}\text { Subject's } \\
\text { Description }\end{array}$ \\
\hline & & & $\begin{array}{l}\text { learning } \\
\text { principles that } \\
\text { are in } \\
\text { accordance } \\
\text { with the needs } \\
\text { of developing } \\
\text { potential for } \\
\text { children with } \\
\text { physical } \\
\text { disabilities. }\end{array}$ \\
\hline 16. & $\begin{array}{l}\text { Motion } \\
\text { Development } \\
\text { Program }\end{array}$ & 10 & $\begin{array}{l}\text { Presenting the } \\
\text { concepts, } \\
\text { principles, } \\
\text { forms and } \\
\text { techniques of } \\
\text { learning the } \\
\text { development } \\
\text { program. }\end{array}$ \\
\hline 17. & $\begin{array}{l}\text { Sustainable } \\
\text { Professional } \\
\text { Development }\end{array}$ & 10 & $\begin{array}{l}\text { Presenting } \\
\text { concepts, } \\
\text { principles and } \\
\text { forms of PKB } \\
\text { (Sustainable } \\
\text { Professional } \\
\text { Development). }\end{array}$ \\
\hline 18. & $\begin{array}{l}\text { Spiritual } \\
\text { Development in } \\
\text { Inclusive } \\
\text { Schools }\end{array}$ & 10 & $\begin{array}{l}\text { Presenting } \\
\text { concepts, } \\
\text { principles, } \\
\text { forms and } \\
\text { techniques of } \\
\text { Spiritual } \\
\text { Development } \\
\text { in Inclusive } \\
\text { Schools }\end{array}$ \\
\hline 19. & $\begin{array}{l}\text { Learning for } \\
\text { Autistic } \\
\text { Children }\end{array}$ & 10 & $\begin{array}{l}\text { Presenting the } \\
\text { concept of } \\
\text { children with } \\
\text { autism, } \\
\text { orientation and } \\
\text { learning } \\
\text { principles that } \\
\text { are appropriate } \\
\text { to the needs of } \\
\text { the } \\
\text { development of } \\
\text { potential } \\
\text { Autistic } \\
\text { children. }\end{array}$ \\
\hline 20. & $\begin{array}{l}\text { Management of } \\
\text { the Behavior of } \\
\text { Autistic } \\
\text { Children }\end{array}$ & 10 & $\begin{array}{l}\text { Presenting } \\
\text { concepts, } \\
\text { forms, analysis } \\
\text { of the behavior } \\
\text { management of } \\
\text { autistic } \\
\text { children, as } \\
\text { well as steps to } \\
\text { manage the }\end{array}$ \\
\hline
\end{tabular}

\begin{tabular}{|c|c|c|c|}
\hline No & Subject & JPL & $\begin{array}{c}\text { Subject's } \\
\text { Description }\end{array}$ \\
\hline & & & $\begin{array}{l}\text { behavior of } \\
\text { autistic } \\
\text { children. }\end{array}$ \\
\hline 21. & $\begin{array}{l}\text { Picture } \\
\text { Exchange } \\
\text { Communications } \\
\text { System (PECS) }\end{array}$ & 10 & $\begin{array}{l}\text { Presenting } \\
\text { concepts, forms } \\
\text { and procedures } \\
\text { for using PECS }\end{array}$ \\
\hline 22. & $\begin{array}{l}\text { Learning for } \\
\text { Children with } \\
\text { Learning } \\
\text { Difficulties }\end{array}$ & 10 & $\begin{array}{l}\text { Presenting the } \\
\text { concept of } \\
\text { children with } \\
\text { learning } \\
\text { difficulties, } \\
\text { orientation and } \\
\text { learning } \\
\text { principles that } \\
\text { are in line with } \\
\text { the potential } \\
\text { development } \\
\text { needs of } \\
\text { children with } \\
\text { learning } \\
\text { difficulties. }\end{array}$ \\
\hline 23. & $\begin{array}{l}\text { ICT-based } \\
\text { Student with } \\
\text { Special Needs } \\
\text { Learning }\end{array}$ & 10 & $\begin{array}{l}\text { Explain the } \\
\text { concepts, } \\
\text { principles and } \\
\text { forms of ICT- } \\
\text { based student } \\
\text { with special } \\
\text { needs learning } \\
\text { and the steps to } \\
\text { develop ICT- } \\
\text { based learning. }\end{array}$ \\
\hline 24. & $\begin{array}{l}\text { Learning Media } \\
\text { for Student with } \\
\text { Special Needs }\end{array}$ & 10 & $\begin{array}{l}\text { Presenting } \\
\text { concepts, } \\
\text { principles and } \\
\text { forms of } \\
\text { adaptive } \\
\text { learning media } \\
\text { for student with } \\
\text { special needs, } \\
\text { as well as steps } \\
\text { for developing } \\
\text { adaptive } \\
\text { learning media. }\end{array}$ \\
\hline 25. & Adaptive Guards & 10 & $\begin{array}{l}\text { Presenting } \\
\text { concepts, } \\
\text { principles and } \\
\text { forms of } \\
\text { adaptive care } \\
\text { and steps for } \\
\text { developing } \\
\text { adaptive care. }\end{array}$ \\
\hline 26. & $\begin{array}{l}\text { Approaches, } \\
\text { Strategies and } \\
\text { Learning } \\
\text { Methods for } \\
\text { Student with }\end{array}$ & 20 & $\begin{array}{l}\text { Presenting } \\
\text { concepts, } \\
\text { principles and } \\
\text { procedures for } \\
\text { scientific, }\end{array}$ \\
\hline
\end{tabular}




\begin{tabular}{|c|c|c|c|}
\hline No & Subject & JPL & $\begin{array}{c}\text { Subject's } \\
\text { Description }\end{array}$ \\
\hline & Special Needs & & $\begin{array}{l}\text { thematic and } \\
\text { integrated } \\
\text { learning } \\
\text { procedures }\end{array}$ \\
\hline 27. & $\begin{array}{l}\text { Student with } \\
\text { Special Needs } \\
\text { Class } \\
\text { Management }\end{array}$ & 10 & $\begin{array}{l}\text { Explain the } \\
\text { concepts, } \\
\text { principles and } \\
\text { forms of } \\
\text { student with } \\
\text { special needs } \\
\text { class } \\
\text { management, } \\
\text { as well as steps } \\
\text { to develop } \\
\text { student with } \\
\text { special needs } \\
\text { class } \\
\text { management. }\end{array}$ \\
\hline 28. & $\begin{array}{l}\text { Learning for } \\
\text { Gifted Children }\end{array}$ & 10 & $\begin{array}{l}\text { Presenting the } \\
\text { concept of } \\
\text { CIBI children, } \\
\text { orientation and } \\
\text { learning } \\
\text { principles that } \\
\text { are in line with } \\
\text { the potential } \\
\text { development } \\
\text { needs of the } \\
\text { gifted children. }\end{array}$ \\
\hline 29. & $\begin{array}{l}\text { Vocational for } \\
\text { Student with } \\
\text { Special Needs }\end{array}$ & 10 & $\begin{array}{l}\text { Presenting } \\
\text { Vocational } \\
\text { concepts, } \\
\text { principles and } \\
\text { procedures for } \\
\text { student with } \\
\text { special needs }\end{array}$ \\
\hline 30. & $\begin{array}{l}\text { Curriculum } \\
\text { Development for } \\
\text { Student with } \\
\text { Special Needs }\end{array}$ & 10 & $\begin{array}{l}\text { Presenting } \\
\text { curriculum } \\
\text { concepts, } \\
\text { principles and } \\
\text { forms of } \\
\text { curriculum } \\
\text { development } \\
\text { for student with } \\
\text { special needs, } \\
\text { as well as } \\
\text { curriculum } \\
\text { development } \\
\text { modification } \\
\text { techniques for } \\
\text { student with } \\
\text { special needs }\end{array}$ \\
\hline 31. & $\begin{array}{l}\text { Syllabus and } \\
\text { lesson plan for } \\
\text { Student with } \\
\text { Special Needs }\end{array}$ & 10 & $\begin{array}{l}\text { Presenting } \\
\text { concepts, forms } \\
\text { and steps for } \\
\text { the preparation } \\
\text { of syllabi and }\end{array}$ \\
\hline
\end{tabular}

\begin{tabular}{|c|c|c|c|}
\hline No & Subject & JPL & $\begin{array}{c}\text { Subject's } \\
\text { Description }\end{array}$ \\
\hline & & & $\begin{array}{l}\text { lesson plan for } \\
\text { student with } \\
\text { special needs. }\end{array}$ \\
\hline 32. & $\begin{array}{l}\text { Learning } \\
\text { Evaluation for } \\
\text { Student with } \\
\text { Special Needs }\end{array}$ & 10 & $\begin{array}{l}\text { Presenting } \\
\text { concepts, } \\
\text { principles and } \\
\text { procedures for } \\
\text { Learning } \\
\text { Evaluation for } \\
\text { student with } \\
\text { special needs }\end{array}$ \\
\hline 33. & $\begin{array}{l}\text { Classroom } \\
\text { Action Research }\end{array}$ & 10 & $\begin{array}{l}\text { Presenting } \\
\text { Class Action } \\
\text { Research } \\
\text { concepts, } \\
\text { principles and } \\
\text { procedures. }\end{array}$ \\
\hline 34. & $\begin{array}{l}\text { Single Subject } \\
\text { Research }\end{array}$ & 10 & $\begin{array}{l}\text { Presenting the } \\
\text { concepts, } \\
\text { principles and } \\
\text { procedures of } \\
\text { Single Subject } \\
\text { Research. }\end{array}$ \\
\hline 35 & $\begin{array}{l}\text { Guidance and } \\
\text { Counseling for } \\
\text { Student with } \\
\text { Special Needs }\end{array}$ & 8 & $\begin{array}{l}\text { Presenting } \\
\text { concepts, } \\
\text { goals, } \\
\text { principles, } \\
\text { principles of } \\
\text { guidance and } \\
\text { counseling, and } \\
\text { applying them } \\
\text { for the benefit } \\
\text { of developing } \\
\text { the potential of } \\
\text { student with } \\
\text { special needs. }\end{array}$ \\
\hline 36. & $\begin{array}{l}\text { Nutrition and } \\
\text { Health in } \\
\text { Student with } \\
\text { Special Needs }\end{array}$ & 6 & $\begin{array}{l}\text { Explain the } \\
\text { concepts, } \\
\text { forms, and } \\
\text { principles of } \\
\text { nutrition and } \\
\text { health in } \\
\text { student with } \\
\text { special needs. }\end{array}$ \\
\hline 37. & $\begin{array}{l}\text { Cooperation } \\
\text { between Parents } \\
\text { and Schools }\end{array}$ & 6 & $\begin{array}{l}\text { Explain } \\
\text { concepts, } \\
\text { forms, and } \\
\text { principles of } \\
\text { cooperation } \\
\text { between } \\
\text { parents and } \\
\text { schools, as well } \\
\text { as steps to } \\
\text { develop } \\
\text { parental } \\
\text { cooperation } \\
\text { with schools. }\end{array}$ \\
\hline
\end{tabular}




\begin{tabular}{|c|l|c|l|}
\hline No & \multicolumn{1}{|c|}{ Subject } & JPL & $\begin{array}{l}\text { Subject's } \\
\text { Description }\end{array}$ \\
\hline 38. & $\begin{array}{l}\text { Project Based } \\
\text { Learning Model }\end{array}$ & 20 & $\begin{array}{l}\text { Presenting } \\
\text { concepts, } \\
\text { principles, and } \\
\text { procedures for } \\
\text { the Project } \\
\text { Based Learning } \\
\text { Model }\end{array}$ \\
\hline 39. & $\begin{array}{l}\text { On the job } \\
\text { learning with } \\
\text { mentoring }\end{array}$ & 50 & $\begin{array}{l}\text { Participants } \\
\text { will be given } \\
\text { the task of } \\
\text { compiling } \\
\text { portfolios, in } \\
\text { the form of } \\
\text { tasks relevant } \\
\text { to the material } \\
\text { put in, in the } \\
\text { form of } \\
\text { teaching } \\
\text { practice reports } \\
\text { in their } \\
\text { respective } \\
\text { Schools } \\
\text { attached with } \\
\text { lesson plan, } \\
\text { Activity Photos }\end{array}$ \\
\hline SUPORTING PROGRAM \\
\end{tabular}

\begin{tabular}{|c|c|c|c|}
\hline 1. & Group dynamics & 4 & $\begin{array}{l}\text { Providing } \\
\text { dynamic } \\
\text { activities to } \\
\text { realize mental, } \\
\text { physical, } \\
\text { academic } \\
\text { preparation as } \\
\text { training } \\
\text { participants. }\end{array}$ \\
\hline 2. & Physical fitness & 6 & $\begin{array}{l}\text { Provide } \\
\text { activities that } \\
\text { can maintain } \\
\text { physical fitness } \\
\text { to be able to } \\
\text { participate in } \\
\text { training } \\
\text { activities } \\
\text { optimally. }\end{array}$ \\
\hline 3. & $\begin{array}{l}\text { Lab Utilization. } \\
\text { student with } \\
\text { special needs }\end{array}$ & 4 & $\begin{array}{l}\text { Providing } \\
\text { direct } \\
\text { experience to } \\
\text { training } \\
\text { participants to } \\
\text { explore } \\
\text { laboratory } \\
\text { utilization for } \\
\text { student with } \\
\text { special needs. }\end{array}$ \\
\hline 4. & Action Plan & 2 & $\begin{array}{l}\text { Providing } \\
\text { technical } \\
\text { instructions to }\end{array}$ \\
\hline
\end{tabular}

\begin{tabular}{|c|c|c|c|}
\hline No & Subject & JPL & $\begin{array}{c}\text { Subject's } \\
\text { Description }\end{array}$ \\
\hline & & & $\begin{array}{l}\text { training } \\
\text { participants to } \\
\text { prepare action } \\
\text { plans after } \\
\text { participating in } \\
\text { the special } \\
\text { guidance } \\
\text { teachers } \\
\text { competency } \\
\text { training } \\
\text { training. }\end{array}$ \\
\hline & & 450 & \\
\hline
\end{tabular}

\section{Competency Acquisition}

Training participants have an understanding of policies and actual issues of developing professionalism in teachers nationally.

The participants of the Training and Education have an understanding of the Local Education Office program in the development and improvement of the competence of special supervisor teachers.

Training participants gain an understanding of Cultural and National Character Education and can analyze social problems in the perspective of Cultural Education and nation's character

Participants have mental-academic understanding and readiness about the competency processes and demands that must be achieved during participating in the special guidance teacher competency training designed and implemented by the PPPPTK TK and PLB or other training institutions

Participants have an understanding of the scientific structure of inclusive education and the actual issues that accompany the development of inclusive education, at the policy, conceptual, and empirical levels, as a frame of mind in the development of the competence of special supervisor teachers.

Participants have a detailed understanding of the four competencies of special guidance teachers and their elaboration in the main tasks as education of children with special needs.

Participants gained an understanding of the background of educational psychology studies for educational practices, concepts and scope of educational psychology, and the benefits of educational psychology for the benefit of student with special needs learning.

The training participants gained an understanding of philosophical, policy, conceptual, management of the implementation of inclusive education, as well as empirical analysis of the implementation of inclusive education in Indonesia.

Participants have the competence to understand the characteristics of student with special needs, explain the concept of identification and assessment, and can make instruments in the implementation of the student with special needs assessment. 


\begin{tabular}{|l|}
\multicolumn{1}{|c|}{ Competency Acquisition } \\
\hline Training participants have the competence to explain \\
the concept of blind people, and identify the \\
orientation and principles of learning that are \\
appropriate to the needs of developing the potential \\
of blind children. \\
Training participants have the competence to be \\
skilled at reading and writing braille. \\
\hline Training participants have the competence to explain \\
the concepts and principles of O \& M learning, and \\
can simulate basic O \& M techniques. \\
\hline Training participants have the competence to explain \\
the concept of deafness, and identify the orientation \\
and principles of learning in accordance with the \\
potential development needs of deaf children. \\
Training participants have the competence to explain \\
the concept of extinction, analysis of the language \\
development of deaf children, and the background of \\
the importance of the BKPBI program for deaf \\
children.
\end{tabular}

Training participants have the competence to explain the principles of BKPBI, and apply BKPBI learning procedures and techniques.

Training participants have the competence to explain the concept of mental retardation, and identify the orientation and principles of learning that are in accordance with the needs of developing the mentally retarded child.

Training participants have the competence to explain the concepts, principles, and forms of self-

development learning programs, and can apply the learning steps of self-development programs.

Training participants have the competence to explain the concept of slow learning children, and identify the orientation and principles of learning that are in accordance with the needs of the development of the potential of slow learning children.

Training participants have the competence to explain the concept of quadriplegic, and identify the orientation and principles of learning that are in accordance with the needs of developing potential children with physical disabilities.

Training participants have the competence to explain the concepts, principles, forms and techniques of teaching and learning programs

Training participants have the competence to explain concepts, principles, forms of PKB (Sustainable Professional Development).

Training participants have the competence to explain the concepts, principles, forms and techniques of Spiritual Development in inclusive Schools

Training participants have the competence to explain the concept of autism, and identify the orientation and principles of learning that are in line with the potential development needs of autistic children. Training participants have the competence to explain concepts, forms, analysis of behavioral management of children with autism, as well as steps to manage behavior of autistic children

\section{Competency Acquisition}

Training participants have the competence to explain the concepts, forms and procedures for using communication development through the PECS Technique

Training participants have the competence to explain the concept of learning difficulties, and identify the orientation and principles of learning that are in line with the potential development needs of children with learning difficulties.

Training participants have the competence to explain the concepts, principles, and forms of ICT-based student with special needs learning and the steps of developing ICT-based learning.

Training participants have the competence to explain concepts, principles, and forms of adaptive learning media for student with special needs, as well as steps for developing adaptive learning media.

Training participants have the competence to explain the concepts, principles, and forms of adaptive care and can implement steps to develop adaptive education.

Training participants have the competence to explain concepts and apply the principles and procedures of scientific, thematic and integrated learning.

Training participants have the competence to explain the concepts, principles and forms of student with special needs class management, as well as the steps to develop student with special needs class management.

Training participants have the competence to explain the gifted student concept, and identify the orientation and principles of learning that are appropriate to the potential development needs of the gifted-talented child.

Training participants have the competence to explain concepts and apply vocational principles and procedures to student with special needs

Training participants have the competence to explain the concepts, principles and forms of curriculum development for student with special needs, and apply curriculum development modification techniques for student with special needs.

Training participants have the competence to explain the concepts and forms of syllabus and lesson plan and to implement the steps in preparing the syllabus and lesson plan

Training participants have the competence to explain concepts and apply the principles and procedures for Learning Evaluation for student with special needs Training participants have the competence to explain concepts and apply the principles and procedures of Class Action Research.

Training participants have the competence to explain the concepts and apply the principles and procedures of Single Subject Research.

Training participants have the competence to explain the concepts, objectives, principles, principles of guidance and counseling, and apply them to the 
IJDS 2018; Vol. 5 No. 2, November 2018, pp. 251-267

ISSN: $2355-2158$, e-ISSN: $2654-4148$

DOI:

\begin{tabular}{|c|}
\hline Competency Acquisition \\
\hline $\begin{array}{l}\text { interests of developing the potential of student with } \\
\text { special needs. }\end{array}$ \\
\hline $\begin{array}{l}\text { Participants have the competence to explain and } \\
\text { apply the principles of nutrition and health to student } \\
\text { with special needs. }\end{array}$ \\
\hline $\begin{array}{l}\text { Education and training participants have the } \\
\text { competence to explain concepts, forms, and } \\
\text { principles of cooperation between parents and } \\
\text { schools, as well as steps to develop parental } \\
\text { cooperation with schools. }\end{array}$ \\
\hline $\begin{array}{l}\text { Training participants have the competence to explain } \\
\text { the concepts and apply the principles and procedures } \\
\text { of the Project Based Learning Model. }\end{array}$ \\
\hline $\begin{array}{l}\text { Training participants have the competence to } \\
\text { practice teaching and create report documents } \\
\text { accompanied by relevant attachments. }\end{array}$ \\
\hline $\begin{array}{l}\text { Training participants show mental, physical, and } \\
\text { academic readiness to follow the entire learning } \\
\text { process. }\end{array}$ \\
\hline $\begin{array}{l}\text { Training participants show physical fitness to be } \\
\text { able to participate in training activities optimally. }\end{array}$ \\
\hline $\begin{array}{l}\text { Training participants gain direct experience to } \\
\text { explore the use of laboratories for student with } \\
\text { special needs. }\end{array}$ \\
\hline $\begin{array}{l}\text { The training participants have the competence to } \\
\text { develop an action plan after participating in a special } \\
\text { guidance teachers competency training. }\end{array}$ \\
\hline
\end{tabular}

